\title{
Between the Eurozone crisis and the Brexit: the decade of British outward FDI into Europe
}

\author{
Andrzej Cieślik ${ }^{1}$ (D) Oleg Gurshev ${ }^{1} \cdot$ Sarhad Hamza ${ }^{2}$
}

Received: 16 June 2021 / Accepted: 22 November 2021 / Published online: 17 December 2021

(c) The Author(s) 2021

\begin{abstract}
This paper investigates the determinants of outward foreign direct investment (OFDI) of British multinational firms in the European Union (EU) and the European Free Trade Association members across 2009-2019 using Bayesian model averaging. We find evidence that supports the existence and dynamic behavior of the East-West structure of FDI between three groups of countries: core-EU, Central and Eastern European economies (CEE), and the Nordics. Further, we document the importance of relative market size, urbanization, the rule of law in attaining horizontal FDI in the core-EU economies. In turn, infrastructure spending and enhanced political stability are the most important drivers for FDI in CEE (post-2000 accession). Finally, our results highlight the negative effects of the Eurozone crisis and Brexit anticipation on British OFDI activity in the region. The findings remain robust when accounting for potential MNE profit shifting to partners such as Ireland, Luxembourg, and alike.
\end{abstract}

Keywords Brexit · Europe · Eurozone crisis · Outward FDI · UK

\section{Introduction}

The last decade saw a steady growth of the British outward FDI (OFDI) stocks into the member countries of the European Union (EU) and the European Free Trade Association (EFTA). Between 2009 and 2019, total British OFDI in Europe grew

\footnotetext{
$\bowtie \quad$ Andrzej Cieślik

cieslik@wne.uw.edu.pl

Oleg Gurshev

o.gurshev@uw.edu.pl

Sarhad Hamza

sarhadhamza@uor.edu.krd

1 Department of Macroeconomics and International Trade Theory, Faculty of Economic Sciences, University of Warsaw, ul. Długa 44/50, 00-241 Warsaw, Poland

2 Department of Administration, Faculty of Humanities, University of Raparin, Kurdistan, Iraq
} 
by nearly $12 \%$, half of which was concentrated in the EU and the EFTA members ${ }^{1}$ (Office for National Statistics 2020). On the other hand, the British multinational firms (MNEs) faced various operational challenges, e.g., the Eurozone crisis, trade disputes, and Brexit, ${ }^{2}$ and were often forced to adapt, and in some cases, establish new subsidiaries abroad (Bloom et al. 2019). While the trade implications of Brexit have been studied to a great degree (Dhingra et al. 2017; Dhingra and Sampson 2019; Oyamada 2020), the FDI dimension has seen little to no empirical work, with only the exception of Breinlich et al. (2020), who document a substantial increase in the number of British OFDI transactions to the EU members just after the Brexit referendum.

To date, the existing literature on British OFDI has investigated a number of topics, e.g. Kneller and Manderson (2012) evaluated the effect of environmental regulations on the pattern of British MNEs activities. Simpson (2012) examined the relationship between the structure of firms' overseas FDI, and its performance in both manufacturing and business services using firm-level OFDI data across 1998-2004. Their findings indicate that the most productive firms are generally sorted into multinational status, and use FDI. Further, they discuss evidence that UK firms invest in low-wage economies, engage in offshoring, and display vertical integration. Following, Maza et al. (2020) studied the determinants of British MNEs in Spain and discovered that the level of wages and infrastructure development to be the main factors of the location choice of British firms. Most recently, Gurshev and Hamza (2021) scrutinized the impact of bilateral investment treaties (BITs) between the UK and its FDI partners and highlighted the dominance of horizontal motive of British OFDI, and the negative effects of participation in BITs. Not surprisingly, besides Maza et al. (2020) and Gurshev and Hamza (2021), the earlier studies made no attempts to analyze the core determinants of British OFDI, and especially, did not provide any detailed treatment of OFDI going in the EU and the EFTA. With the exception of the latter study, there has been little work on disentangling the potential puzzle between British OFDI and the ongoing profit shifting of MNEs vis-à-vis the FDI channel, especially given the economic backdrop of the last decade. Henceforth, we argue that a thorough investigation is in order as understanding the core determinants of British OFDI in the EU and the EFTA economies remains a relevant research topic.

As of 2019, the bulk of British OFDI was located in the Benelux and other parts of Western Europe, including the Netherlands (US\$ 198.84 billion), Luxembourg (US\$ 122.44 billion), Spain (US\$ 96.06 billion), France (US\$ 96.01 billion), and Ireland (US\$ 70.27 billion). Figure 6 (Appendix) illustrates the partner distribution of British OFDI between 2009 and 2019. The majority of stocks were located in sectors such as financial services (US\$275.47 billion), information and communication (US\$ 110.44 billion), petroleum and chemicals (US\$ 91.430 billion), retail and wholesale (US\$ 54.30 billion), food and tobacco (US\$ 47.67 billion). Figure 7 (Appendix) shows

\footnotetext{
1 The detailed spatial distribution of British OFDI stocks in the EU and the EFTA members between 2009 and 2019 (average) is pictured in Fig. 8 (Appendix).

2 Although the impact of the Brexit on FDI is still uncertain, most studies predict an aggregate reduction of British OFDI between 12 and $28 \%$ as a result of potential market access issues and diminishing interest from investors in the post-Brexit UK (Campos et al. 2019; Welfens 2017; Welfens and Baier 2018; Serwicka and Tamberi 2018).
} 
the sectoral distribution of the British OFDI across 2016-2019. ${ }^{3}$ Given the existing financial links of the UK with some of the EU economies (Ireland, Luxembourg, and alike), the analysis undertaken in this paper assumes that the mass of outgoing FDI to the aforementioned locations represents transit of financial transactions due to corporate tax avoidance and profit shifting ${ }^{4}$ rather than real-world investments and physical operations of MNEs. This is because the existing literature documents significant amounts of quantitative evidence in regards to the profit-shifting activities of MNEs associated with the above-mentioned locations ${ }^{5}$ (Hines and Rice 1994; Davies et al. 2018; Damgaard et al. 2019). In particular, we hypothesize that the existing results of Breinlich et al. (2020) that document an increase in the number of financial transactions between the UK and the EU before the Brexit, at least in part, represent round-tripping via FDI because of pooled estimation with Ireland, the Netherlands, and Luxembourg present in the sample. Further, count data could be subject to bias due to the existence of pass-through transactions that are simply recorded but have nothing to do with the actual operations of MNEs.

The main goal of this paper is to provide back-of-the-envelope empirical calculations of location choice of British MNEs in the EU and the EFTA economies, using a general framework of cross-country distribution of MNEs developed in Bergstrand and Egger (2007) as a point of departure for variable selection and identification of FDI motives. Because of the fact that there could be additional covariates that influence MNEs' location decision, e.g., tax policies, local institutions, and certain geographic features, we take the Bayesian approach, as it is able to accommodate uncertainty regarding the potential choice of covariates beyond the initial theoretical set of variables. In particular, we use the Bayesian model averaging (BMA) estimation method, which enables us to investigate a diverse set of possible covariates and select the most promising candidates as well as estimate average regression coefficients inside of model space. While the use of BMA is not entirely new to the economic literature (Sala-i-Martin et al. 2004), it has been becoming increasingly popular to empirically study all kinds of FDI data. Notable examples are Blonigen and Piger $(2011,2014)$, Camarero et al. (2019), and Camarero et al. (2021). Though, to the best of our knowledge, this method has not been used yet to study the determinants of British OFDI. Lastly, because of the potential data issues regarding the actual degree (or volume) of round-tripping, the analysis undertaking in this paper attempts at bridging the gap between real and round-trip FDI with the use of data-matching between the national British OFDI stock data and Damgaard et al. (2019) estimates.

The contribution of this paper to the literature is severalfold. First, in contrast to the previous studies that employ BMA, the featured methodology is built from a general equilibrium theory of cross-country distribution of MNEs, which is then applied to British OFDI data. Further, the paper analyzes the extent and degree of effects surrounding profit shifting via the FDI channel by comparing reported and estimated stocks for the selected pool of round-trip FDI partners. Next, the paper

\footnotetext{
3 This is due to the scope of how the Office for National Statistics reports sectoral FDI data.

4 For example, in 2017, the share of FDI coming from the UK to Luxembourg from non-Special Purpose Entities accounted for only $5 \%$ of the total FDI stock volume.

5 For example, Damgaard et al. (2019) estimate, that for financial centres such as Luxembourg and the Netherlands, real FDI can be as low as $5 \%$ of the total FDI stock.
} 
adds to the discussion on the topic of FDI determinants in Europe by examining important drivers of FDI into two subgroups of countries: pre-2000 and post-2000 EU accession members (the East-West structure of inward FDI in the EU). Finally, the paper examines the effects of the Eurozone crisis and Brexit on British OFDI in Europe.

Few facts arise from our investigation: first, we show the importance of host country characteristics such as size, level of urbanization, and the rule of law in driving horizontal FDI in large (pre-2000) EU economies. Such findings are similar to what Blonigen and Piger (2011) obtain for their FDI data, while in comparison with Camarero et al. (2019, 2021), our results support a more pronounced role of GDP-related covariates. Second, the analysis finds shifting of vertical FDI to CEE and the Nordic economies from the core-EU members. This fact extends previously found empirical evidence in Disdier and Mayer (2004), who underline the stark East-West structure of FDI in Europe. Our addition is the finding of a dynamic behavior within this structure not only East to West, but also West to North. Further, we report the negative relationship between the government effectiveness and FDI that can imply the willingness of MNEs to participate in domestic corruption mechanisms in order to obtain local permits or licenses in the host economy. This result supports previously obtained evidence on MNE operations and hosts' corruption in Egger and Winner (2005). Third, as for post-2000 EU accession members, our findings emphasize the importance of tax revenue (e.g., infrastructure spending and public investment) and enhanced political stability in attracting FDI. The role of public investment and infrastructure has been highlighted in Justesen (2008), while the role of political stability and MNE activity has been emphasized in studies of Resnick (2001), Carmignani (2003) and Busse and Hefeker (2007), and our analysis supports this relationship. Finally, the results document the negative effects of the Eurozone crisis and Brexit anticipation on FDI stock levels in the EU and the EFTA.

The remainder of the paper organizes as follows. Section 2 introduces basic notions behind FDI, our baseline theoretical framework, and research hypotheses. Section 3 describes statistical data and empirical methodology. Section 4 reports and discusses estimation results. Section 5 concludes.

\section{Theoretical framework}

This section introduces the baseline framework for the identification of FDI motives. The literature on FDI and MNEs distinguishes between two types of motives for FDI: horizontal and vertical. In the horizontal motive of FDI, firms face the tradeoff between maximizing proximity of production to customers and export (or trade) costs. ${ }^{6}$ While, in the vertical motive, FDI is related to countries' differences in relative factor endowments, where MNEs exploit cost variation between production factors in different countries. In sum, the decision of firms to engage in horizontal FDI would be driven by the market characteristics (size, population, trade barriers, etc.) of the

\footnotetext{
6 The mechanism of firm choice between horizontal integration and exporting is well demonstrated in Helpman et al. (2004).
} 
host country, whereas vertical FDI would look for cost competitiveness of production factors (capital, labor, natural resources, etc.) among the group of countries.

To distinguish between horizontal and vertical motives, this paper relies on a general equilibrium model of MNEs location choice developed in Bergstrand and Egger (2007) - knowledge-and-physical capital model as it allows for clear differentiation between the horizontal and vertical reasons for FDI using the country-level characteristics, e.g., market size, factor endowments, bilateral barriers to trade, etc. ${ }^{7}$ Its three core assumptions are as follows: first, services of knowledge-based activities such as R\&D, patents, and know-how can be geographically separated from physical production and supplied to operating facilities when needed at low costs. Second, the knowledge-based activities are skilled labor intensive relative to production. The first two assumptions imply the vertical fragmentation of MNE operations, where skilled-intensive facilities are located in the advanced (human capital abundant) economies, while more routine manufacturing takes place in low-cost location. Finally, the knowledge-based services have a partial joint-input characteristic, so that they can be used at the same time by many production facilities. This creates firm-level economies of scale and motivates the horizontal investments that serve the domestic market by supplying goods similar to the ones available in the parent country. Thus, the resulting trade and investment interactions between countries in the model are endogenous.

The model assumes two goods $\left(X\right.$ and $Y$ ), three countries $\left(H, F\right.$, and $\left.R O W^{8}\right)$, and three factors of production: unskilled labor $(L)$, skilled labor $(S)$, and physical capital $^{9}(K) . L$ and $S$ are internationally immobile, while $K$ is mobile in the sense that firms will endogenously choose the optimal allocation of domestic physical capital between $H$ and $F$ to maximize profits. The setup of firm headquarters requires the host (or home) to be endowed with skilled labor, while the setup of a plant requires the host (or home) to have physical capital. ${ }^{10}$ Good $Y$ is unskilled labor intensive and requires physical capital only, and is produced under constant returns to scale in a perfectly competitive industry, while good $X$ is skilled labor intensive and produced under increasing returns to scale at the plant-level subject to Cournot oligopoly with free market entry and exit. With such market structure, there are several types of firms that can arise in the equilibrium: national firms (N-type firms) that serve domestic market and export abroad, horizontally integrated firms (H-MNEs) with two plants in both $H$ and $F$ countries with no international trade, and vertically integrated firms (V-MNEs) that maintain headquarters and plant in different countries with exports from an affiliate to a parent.

\footnotetext{
7 The model is an extension of the original cross-country MNE theory developed in Carr et al. (2001), and Markusen, (2002).

8 Introduction of a Rest of the World helps in explaining the "complementarity" of bilateral affiliate sales and trade with respect to country pair's economic size and similarity. As bilateral FDI empirically tends to be maximized when the home country's GDP is larger than the hosts. This allows two-country H-MNEs, and three-country H-MNEs to surface in the equilibrium.

9 The use of physical capital in the model is especially useful since much of the Central and Eastern Europe still remains relative capital scarce.

10 This assumption allows the "coexistence" of H-MNEs and N-type firms in the equilibrium for two identically sized countries.
} 
The cross-country distribution of these three types of firms is driven by country-pair endowment characteristics. For example, N-type firms arise in the equilibrium if one of the three countries $(H, F$, or $R O W)$ is relatively larger and trade costs are low, which encourages domestic production and exports to a smaller country. H-MNEs become important once both $H$ and $F$ are similar in size and factor endowments, while bilateral trade costs are high. Firms will find it profitable to locate themselves in country $F$ and serve local market to avoid transport and trade costs. However, if countries have different factor endowments and trade costs are low, firms prefer to specialize vertically and leverage the variation in skilled and unskilled labor between $H$ and $F$. Finally, the model allows all three types of firms to coexist in the equilibrium based on the initial set of calibration parameters on size, endowment, and trade cost characteristics.

While the original model does not feature closed-form solutions, the currently available data offer a number of proxies that are suitable to quantify levels of physical capital, human capital endowments, market size, distance, and bilateral barriers. Hence, the model can be operationalized by estimating a space of linear models that are initially based on the aforementioned country characteristics. However, because the model is unable to account for profit shifting via the FDI channel, this paper relies on data matching between different levels of FDI equity owned by MNEs to produce counterfactual analysis.

When put into the studied context, it is expected that the model should find the presence of both horizontal and vertical motives for FDI because the host economies of the EU and the EFTA are heterogeneous and can be at least split into two groups: large capital-rich economies (France, Germany, Italy, and others), and relatively smaller and capital scarce economies of Central and Eastern Europe (Czech Republic, Poland, Hungary, and others). In this regard, previous research found a very stark East-West structure of inward FDI into Europe. For example, for French investors, agglomeration (market-size related) effects were found to be less strong in CEE countries than coreEU members, but with an emphasis on institutional quality (Disdier and Mayer 2004). Further, because destinations like Ireland, Luxembourg, or the Netherlands feature relatively high endowments of skilled labor (on aggregate level), there is a strong overlap between vertical FDI activity and round-tripping in these destinations. Hence, we suspect that variables that are often used for vertical FDI identification (e.g. skilled labor proxy) could be biased because of the above-mentioned destinations present in the sample. ${ }^{11}$ Lastly, because of the disruptive effects of both the Eurozone crisis and Brexit, the analysis assumes the existence of shocks to coordination between MNEs' headquarters and affiliates with the overall result being negative for both horizontal and vertical MNEs. All in all, we test the following hypotheses:

- Hypothesis 1: British MNEs locate horizontal FDI in the core EU economies of Western Europe and place vertical FDI in Eastern and Northern Europe.

- Hypothesis 2: Presence of round-trip FDI partners' stock in the global sample leads to a biased estimation of the vertical motive of FDI in relation to cost advantages in factor endowments.

\footnotetext{
11 Such logic does not apply to the physical capital proxy as round-trip FDI essentially transits between destinations and has nothing to do with the real stock of physical capital in the host economy.
} 
- Hypothesis 3: Both the Eurozone crisis and Brexit anticipation has had a negative impact on the volume of British OFDI stocks in the EU and the EFTA members.

\section{Empirical methodology and data}

\subsection{Empirical methodology}

As we rely on a general theory of cross-country distribution of MNEs, the analysis starts with a typically "narrow" set of covariates that is conventional to knowledge and physical capital model: factor endowments, market size, geographical proximity, and bilateral barriers to trade and investments. However, because of the fact, that there could be additional covariates that influence MNEs' location decision (e.g. tax collection, domestic institutions, access to major trading routes, etc.), we take the Bayesian approach, as it is able to accommodate uncertainty regarding the potential choice of covariates beyond the initial theoretical set (Blonigen and Piger 2014). Hence, this paper uses BMA as it supports the study of an extraordinary large covariate space, and its output can be interpreted within the existing theory to identify types of FDI activity.

The estimating equation in the generalized form is specified as follows:

$$
M_{\gamma}: y=X_{0} \alpha+X_{\gamma} \beta_{\gamma}+\epsilon, \epsilon \sim \mathrm{N}\left(\mu, \sigma^{2} I\right)
$$

where $M$ is the model space and contains $2^{P}$ competing models, $\gamma$ is a $p$-dimensional binary vector $\gamma=\left(\gamma_{1}, \ldots, \gamma_{p}\right)$ to identify competing models, $y$ is the $n$-dimensional vector of observations for the dependent variable (inward FDI stock for a given host), $X_{\gamma}$ is the $n \times p_{\gamma}$ matrix of potential FDI determinants in $X$, and $\beta_{\gamma}$ is the vector of linear regressors. The resulting model space consists of 137 billion competing models $\left(\sim 2^{37}\right)$.

Alternative model comparison is based on the posterior probability that some $M_{\gamma}$ is the true model that generated the data. Formally, the model selection problem is defined by the Bayes theorem:

$$
\operatorname{Pr}\left(M_{\gamma} \mid y\right)=\frac{m_{\gamma}(y) \operatorname{Pr}\left(M_{\gamma}\right)}{\sum_{\gamma} m_{\gamma}(y) \operatorname{Pr}\left(M_{\gamma}\right)}
$$

where $\operatorname{Pr}\left(M_{\gamma}\right)$ is the prior probability that $M_{\gamma}$ is the true model and $m_{\gamma}$ is the integrated likelihood with respect to the prior $\pi_{\gamma}$ :

$$
m_{\gamma}(y)=\int f_{\gamma}\left(y \mid \beta_{\gamma}, \alpha, \sigma\right) \pi_{\gamma}\left(\beta_{\gamma}, \alpha, \sigma^{2}\right) \mathrm{d} \beta_{\gamma} \mathrm{d} \alpha \mathrm{d} \sigma^{2}
$$

Posterior inclusion probabilities for each competing variable can be summarized:

$$
p\left(x_{\gamma} \mid y\right)=\sum_{\left\{M_{I}: x_{\gamma} \in M_{I}\right\}} P\left(M_{I} \mid y\right), \quad \gamma=1,2, \ldots, p
$$


Following Bayarri et al. (2012), we include the "Robust prior" for the regression parameters:

$$
\pi_{\gamma}^{R}\left(\alpha, \beta_{\gamma}, \sigma\right)=\sigma^{-1} N_{p \gamma}\left(\beta_{\gamma} \mid 0, g \Sigma_{\gamma}\right)
$$

where $\Sigma_{\gamma}=\sigma^{2}\left(V_{\gamma}^{T} V_{\gamma}\right)^{-1}$, with

$$
V_{\gamma}=\left(I_{n}-X_{0}\left(X_{0}^{T} X_{0}\right)^{-1} X_{0}^{T}\right) X_{\gamma}
$$

and

$$
g \sim p_{\gamma}^{R}(g)=\frac{1}{2} \sqrt{\frac{1+n}{\left(p_{\gamma}+p_{0}\right)}}(g+1)^{-3 / 2}, g>\frac{1+n}{\left(p_{\gamma}+p_{0}\right)}-1
$$

where $g$ is always positive, as it ensures criteria for measurement invariance (chosen units of measurement do not affect Bayesian answers), and that $p_{\gamma}^{R}(g)$ is a proper density. The advantage of the "Robust prior" is its ability to obtain closed-form Bayes posterior inclusion probabilities for the employed covariates in integral (3), and statistical robustness of the obtained parameters.

The prior distribution over the model space is the Scott-Berger prior as it allows controlling for multiplicity with the prior probabilities $\operatorname{Pr}\left(M_{\gamma}\right)$ (Scott and Berger 2006). Its function is to assign a uniform probability to models of the same dimension $\left(p_{\gamma}+p_{0}\right)$. The Scott-Berger prior is defined as:

$$
\operatorname{Pr}\left(H_{\gamma}\right)=\left((p+1)\left(\begin{array}{c}
p \\
p_{\gamma}
\end{array}\right)\right)^{-1}
$$

Additional approximations are done using Gibbs sampling, which is a Markov Chain Monte Carlo (MCMC) algorithm that samples from a resulting model space and yields the reported probability values of the posterior inclusion probabilities of the covariates. We run through 100,000 iterations, the probabilities stabilize at approximately 6000 mark, and the detailed evolution of the inclusion probabilities with the iterations in Gibbs sampling is illustrated in Fig. 9 of Appendix. The proposed econometric approach is implemented in $\mathrm{R}$ using statistical package Bayes VarSel (Garcia-Donato and Forte 2018). We rely on the function GibbsBvs to obtain reported posterior inclusion probabilities of covariates, and the function BMAcoeff to obtain posterior mean of the model's coefficients, both of the above-mentioned functions are developed by Garcia-Donato and Martinez-Beneito (2013).

\subsection{Data description}

Data on British OFDI are collected from the annual reports of the Office for National Statistics (2020). In particular, data are equity stocks owned by the UK-registered 
Table 1 Sample of countries used in the estimation. Source Own summary

Global sample

Round-trip partners

Pre-2000 EU accession subgroup

Post-2000 EU accession subgroup
Austria, Belgium, Bulgaria, Croatia ${ }^{a}$, Cyprus, Czech Republic, Denmark, Estonia, Finland, France, Germany, Greece, Hungary, Italy, Ireland, Latvia, Lithuania, Luxembourg, Malta, the Netherlands, Norway, Poland, Portugal, Romania, Slovakia, Slovenia, Spain, Sweden, Switzerland

Cyprus, Ireland, the Netherlands, Luxembourg, Switzerland

Austria, Belgium, Denmark, Finland, France, Germany, Greece, Italy, Portugal, Spain, Sweden

Bulgaria, Croatia, Czech Republic, Estonia, Hungary, Latvia, Lithuania, Malta, Poland, Romania, Slovakia, Slovenia

Round-trip partners are selected based on the existing quantitative evidence in Hines and Rice (1994), Davies et al. (2018) and Damgaard et al. (2019).

${ }^{a}$ We include bilateral outward FDI stocks to Croatia and treat it as the EU member for the duration of the studied period despite its de-facto accession in 2013.

firms in the EU and the EFTA member countries across 2009-2019. The choice of stock data is dictated by the argument of Blonigen and Piger (2014, p. 782), that stock data represent "the long-run factors that explain the distribution of FDI." The reported data contain disinvestments and missing observations ${ }^{12}(0.65 \%$ and $3.59 \%$ of the total sample, respectively); the number of observations for the complete partner sample is 306. The sample of host countries is illustrated in Table 1.

Data on market size and relative factor endowments are sourced from the most recent version of the Penn World Table 10.0 (Feenstra et al. 2015). Distance-related costs between the UK and the host country are expressed as geographical proximity, which is measured as a distance between London and the capitals of particular partner countries (in $\mathrm{km}$ ). The distance data are sourced from the Centre d'Etudes Prospectives et d'Informations Internationales gravity database (CEPII 2021). This baseline dataset is then augmented with additional explanatory variables, which proxy for market access, national taxation, population, industrial development, institutional characteristics, infrastructure, and geographic features (World Bank 2021; Eurostat 2021). In addition, we use a range of dummies and interaction terms that proxy common language, currency area participation, membership in the EU, or EFTA, etc. Table 2 describes the set of used explanatory variables.

\section{Empirical results}

This section presents and discusses estimation results from the estimation of BMA on British OFDI data in the EU and the EFTA economies. The analysis comes in five parts: first, the results for global sample that features original stock data are discussed (general

\footnotetext{
12 Missing observation and disinvestments are related to stocks located in Bulgaria, Croatia, and Cyprus. These observations are omitted from the estimation as we rely on the logarithmic transformation of FDI stock data in contrast to the existing Poisson PML applications (Santos Silva and Tenreyro 2006). Additionally, because of the log-linearized model specification for the BMA analysis, the obtained results may suffer from selection bias (Eicher et al. 2012).
} 
Table 2 Description of variables used in the estimation. Source Own summary

\begin{tabular}{|c|c|c|}
\hline Variable & Definitions & Data sources \\
\hline FDI & $\begin{array}{l}\text { Directional international investment positions of British } \\
\text { firms abroad analyzed by area and main country. The } \\
\text { data are reported in accordance with the International } \\
\text { Monetary Fund's 6th manual on the balance of } \\
\text { payments and investment position standards (IMF } \\
\text { 2019). Originally reported in British pounds, then } \\
\text { converted to US\$ dollars through Pacific exchange rate } \\
\text { (annual average) (Antweiler 2021) }\end{array}$ & $\begin{array}{l}\text { Office for National } \\
\text { Statistics } \\
\text { Damgaard et al. } \\
\text { (2019) }\end{array}$ \\
\hline gdp_diff & $\begin{array}{l}\text { Squared difference of host and parent GDP's (in constant } \\
2017 \text { US } \$ \text { million), log } \\
\operatorname{In}\left[\left(Y_{i t}-Y_{j t}\right)^{2}\right]\end{array}$ & Penn World Table 10 \\
\hline k_diff & $\begin{array}{l}\text { Physical capital difference, adjusted for the number of } \\
\text { employed population (in constant } 2017 \text { US\$ million), } \\
\log \\
\quad \ln \left[\left|\frac{K_{i t}}{L_{i t}}-\frac{K_{j t}}{L_{j t}}\right|\right]\end{array}$ & Penn World Table 10 \\
\hline h_diff & $\begin{array}{l}\text { Human capital difference, adjusted for the number of } \\
\text { employed population, log } \\
\ln \left[\left|\frac{H_{i t}}{L_{i t}}-\frac{H_{j t}}{L_{j t}}\right|\right]\end{array}$ & Penn World Table 10 \\
\hline gdp_sum & $\begin{array}{l}\text { Sum of host and parent real GDPs (in constant } 2017 \text { US\$ } \\
\text { million), log } \\
\ln \left[Y_{i t}+Y_{j t}\right]\end{array}$ & Penn World Table 10 \\
\hline gdp_sim & $\begin{array}{l}\text { Share of host real GDP in the sum of host and parent } \\
\text { GDP * share of parent real GDP in the sum of host and } \\
\text { parent GDP, log } \\
\ln \left[\frac{Y_{i t}}{Y_{i t}+Y_{j t}} * \frac{Y_{j t}}{Y_{i t}+Y_{j t}}\right]\end{array}$ & Penn World Table 10 \\
\hline dist & $\begin{array}{l}\text { Geographical distance between home and host countries, } \\
\log \text { (between capital cities, in km) }\end{array}$ & CEPII \\
\hline emp_pop & Total employed population in host country, millions, log & $\begin{array}{l}\text { World Development } \\
\text { Indicators }\end{array}$ \\
\hline urban_pop & $\begin{array}{l}\text { Total urban population in host country ( } \% \text { of total } \\
\text { population), millions, } \log \end{array}$ & $\begin{array}{l}\text { World Development } \\
\text { Indicators }\end{array}$ \\
\hline total_pop & Total population in host country, millions, log & $\begin{array}{l}\text { World Development } \\
\text { Indicators }\end{array}$ \\
\hline $\operatorname{tax}$ & Tax revenue in host country ( $\%$ of GDP), log & $\begin{array}{l}\text { World Development } \\
\text { Indicators }\end{array}$ \\
\hline industry & Industry, value added in host country ( $\%$ of GDP), log & $\begin{array}{l}\text { World Development } \\
\text { Indicators }\end{array}$ \\
\hline S_trade & Trade in services ( $\%$ of GDP), log & $\begin{array}{l}\text { World Development } \\
\text { Indicators }\end{array}$ \\
\hline tf_host & Host's trade freedom index & Heritage Foundation \\
\hline tc_uk & Parent's trade freedom index & Heritage Foundation \\
\hline
\end{tabular}


Table 2 (continued)

\begin{tabular}{|c|c|c|}
\hline Variable & Definitions & Data sources \\
\hline infl_host & Host's domestic inflation & $\begin{array}{l}\text { World Development } \\
\text { Indicators }\end{array}$ \\
\hline infl_parent & Parent's domestic inflation & $\begin{array}{l}\text { World Development } \\
\text { Indicators }\end{array}$ \\
\hline gdp_diff_k & $\begin{array}{l}\text { Interaction term between market size difference and } \\
\text { physical capital difference, log }\end{array}$ & Own calculation \\
\hline & $\operatorname{In}\left[\left(Y_{i t}-Y_{j t}\right)^{2}\right] * \ln \left[\left|\frac{K_{i t}}{L_{i t}}-\frac{K_{j t}}{L_{j t}}\right|\right]$ & \\
\hline gdp_diff_h & $\begin{array}{l}\text { Interaction term between market size difference and } \\
\text { human capital difference, log }\end{array}$ & Own calculation \\
\hline & $\operatorname{In}\left[\left(Y_{i t}-Y_{j t}\right)^{2}\right] * \ln \left[\left|\frac{H_{i t}}{L_{i t}}-\frac{H_{j t}}{L_{j t}}\right|\right]$ & \\
\hline \multirow[t]{2}{*}{ tc_h } & $\begin{array}{l}\text { Interaction term between host's trade barriers and human } \\
\text { capital difference, log }\end{array}$ & Own calculation \\
\hline & $\mathrm{TF}_{\mathrm{HOST}} * \ln \left[\left|\frac{H_{i t}}{L_{i t}}-\frac{H_{j t}}{L_{j t}}\right|\right]$ & \\
\hline stab & $\begin{array}{l}\text { Political stability and absence of violence/terrorism in the } \\
\text { host country, measures perceptions of the likelihood of } \\
\text { political instability, including terrorism, percentile rank, } \\
\log \end{array}$ & $\begin{array}{l}\text { World Development } \\
\text { Indicators }\end{array}$ \\
\hline voice & $\begin{array}{l}\text { Perceptions of the extent to which a host country citizens } \\
\text { are able to participate in selecting their government, } \\
\text { freedom of association, and a free media, percentile } \\
\text { rank, log }\end{array}$ & $\begin{array}{l}\text { World Development } \\
\text { Indicators }\end{array}$ \\
\hline gov & $\begin{array}{l}\text { Perceptions of the quality of public services, the quality } \\
\text { of the civil service and the degree of its independence } \\
\text { from political pressures, percentile rank, log }\end{array}$ & $\begin{array}{l}\text { World Development } \\
\text { Indicators }\end{array}$ \\
\hline regq & $\begin{array}{l}\text { Perceptions of the ability of the government to formulate } \\
\text { and implement sound policies and regulations and } \\
\text { promote private sector, percentile rank, log }\end{array}$ & $\begin{array}{l}\text { World Development } \\
\text { Indicators }\end{array}$ \\
\hline law & $\begin{array}{l}\text { Perceptions of the extent to which agents have confidence } \\
\text { in and abide by the rules of society, quality of contract } \\
\text { enforcement, property rights, percentile rank, log }\end{array}$ & $\begin{array}{l}\text { World Development } \\
\text { Indicators }\end{array}$ \\
\hline corrup & $\begin{array}{l}\text { Perceptions of the extent to which public power is } \\
\text { exercised for private gain in the host country, percentile } \\
\text { rank, log }\end{array}$ & $\begin{array}{l}\text { World Development } \\
\text { Indicators }\end{array}$ \\
\hline ports & $\begin{array}{l}\text { Dummy variable, reflects if host has a major trading } \\
\text { seaport (by volume of trade) }\end{array}$ & Eurostat \\
\hline landlocked & Dummy variable, reflects if host is landlocked & Own calculation \\
\hline brexit_r & $\begin{array}{l}\text { Dummy variable, reflects parent's country Brexit } \\
\text { referendum vote }\end{array}$ & Own calculation \\
\hline brexit_a & $\begin{array}{l}\text { Dummy variable, reflects the process of parent's } \\
\text { withdrawal from the European Union }\end{array}$ & Own calculation \\
\hline phantom & $\begin{array}{l}\text { Dummy variable, reflects if host is a well-known } \\
\text { round-trip FDI partner }\end{array}$ & Own calculation \\
\hline
\end{tabular}


Table 2 (continued)

\begin{tabular}{|c|c|c|}
\hline Variable & Definitions & Data sources \\
\hline $\mathrm{eu}$ & $\begin{array}{l}\text { Dummy variable, reflects if host is a member of the } \\
\text { European Union }\end{array}$ & Own calculation \\
\hline efta & $\begin{array}{l}\text { Dummy variable, reflects if host is a member of the } \\
\text { European Free Trade Association }\end{array}$ & Own calculation \\
\hline lang_ger & $\begin{array}{l}\text { Dummy variable, reflects if host has German as an official } \\
\text { language }\end{array}$ & Own calculation \\
\hline lang_eng & $\begin{array}{l}\text { Dummy variable, reflects if host has English as an official } \\
\text { language }\end{array}$ & Own calculation \\
\hline lang_fr & $\begin{array}{l}\text { Dummy variable, reflects if host has French as an official } \\
\text { language }\end{array}$ & Own calculation \\
\hline euro & $\begin{array}{l}\text { Dummy variable, reflects if host is a member of the } \\
\text { Eurozone }\end{array}$ & Own calculation \\
\hline core & $\begin{array}{l}\text { Dummy variable, reflects if host was one of the founders } \\
\text { of the European Coal and Steel Community (Belgium, } \\
\text { France, Italy, Luxembourg, the Netherlands, and } \\
\text { Germany) }\end{array}$ & Own calculation \\
\hline greek & $\begin{array}{l}\text { Dummy variable, reflects the Eurozone area currency } \\
\text { crisis }\end{array}$ & Own calculation \\
\hline
\end{tabular}

case). Then, we report results for the case, when we apply and match Damgaard et al. (2019)'s decomposition of stock data to the selected round-trip destinations (decomposed case). Further, the results for restricted sample that completely exclude round-trip FDI are considered (restricted case). Finally, the section ends with two subgroup estimations that consider pre-2000 and post-2000 EU accession members.

The results are structured as follows: the reported posterior inclusion probabilities (PIP) reflect the marginal importance of different covariates of British MNEs location choice. Generally, the BMA literature considers PIP value ${ }^{13}$ for a regressor from 50 to $75 \%$ weak, from 75 to $95 \%$ positive, from 95 to $99 \%$ strong, and > $99 \%$ very strong (Raftery 1995). For the clarity of exposition, we report only those variables that obtain PIP value above the threshold of $90 \%$ with their posterior means. The estimated PIP values are shown in Figs. 1, 2, 3, 4, 5. Detailed numerical outputs can be found in Tables 3, 4, 5, 6, 7 (Appendix), while convergence graphs for each case are demonstrated in Fig. 9 (Appendix).

Figure 1 reports the general case results, robust PIP values ${ }^{14}$ are obtained for the variables representing human capital difference (h_diff: + 4.56), joint market size (gdp_sum: + 6.68), geographical proximity (dist: - 0.94), market size similarity (gdp_sim: +2.73 ), total and urban population in the host country (total_pop: -2.98 ;

\footnotetext{
13 When combined together, variables with an inclusion probability greater than $50 \%$ (or 0.5 in the Figures) define a median probability model (MPM) and under general conditions, the MPM can be considered as an optimal model for analytical purposes and prediction (Barbieri and Berger 2004).

14 We acknowledge that interpreting both signs and values must be done with caution.
} 


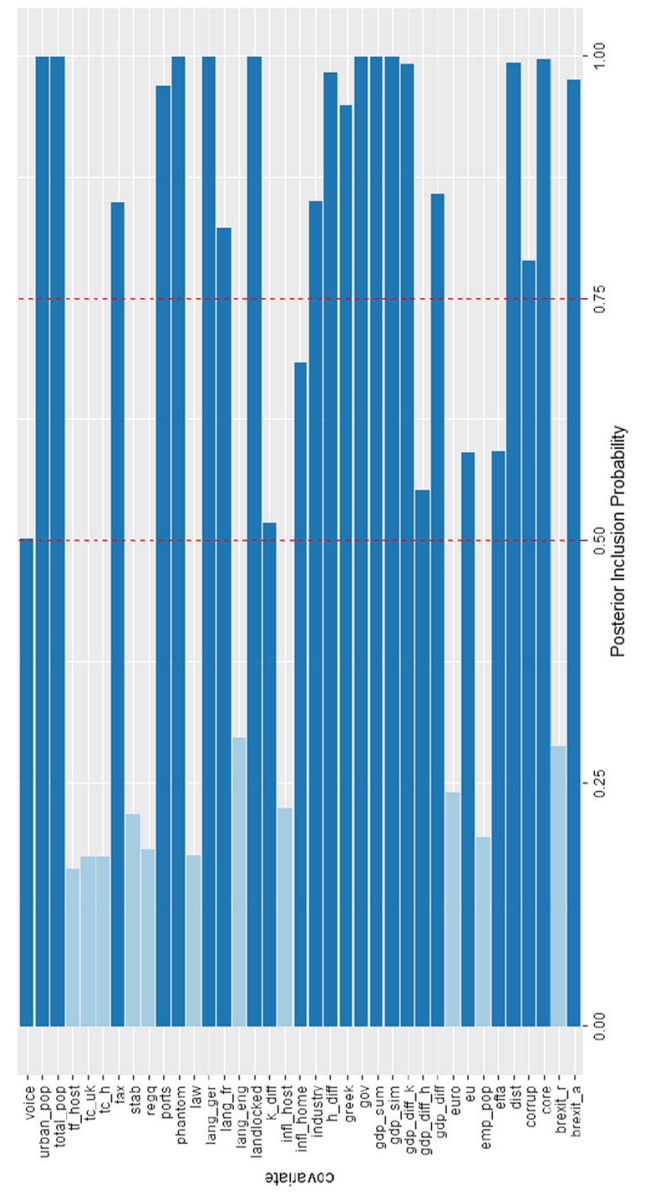

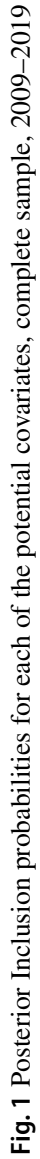




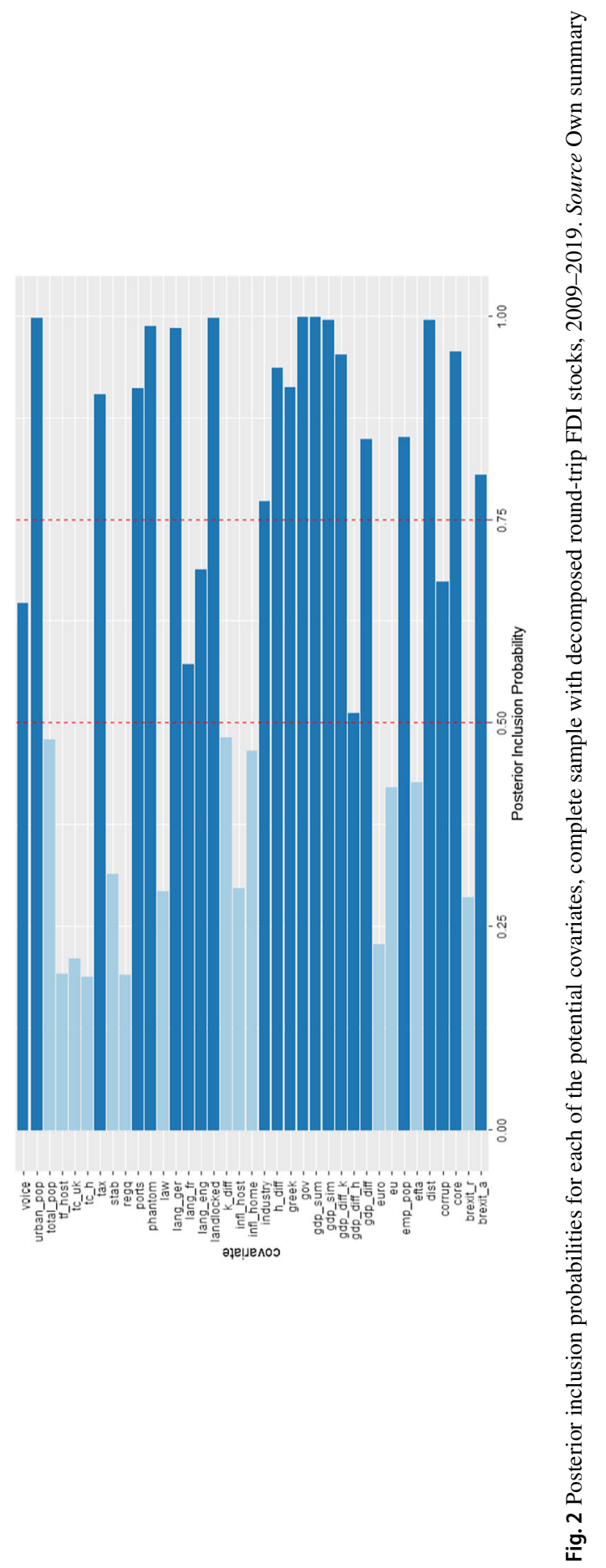




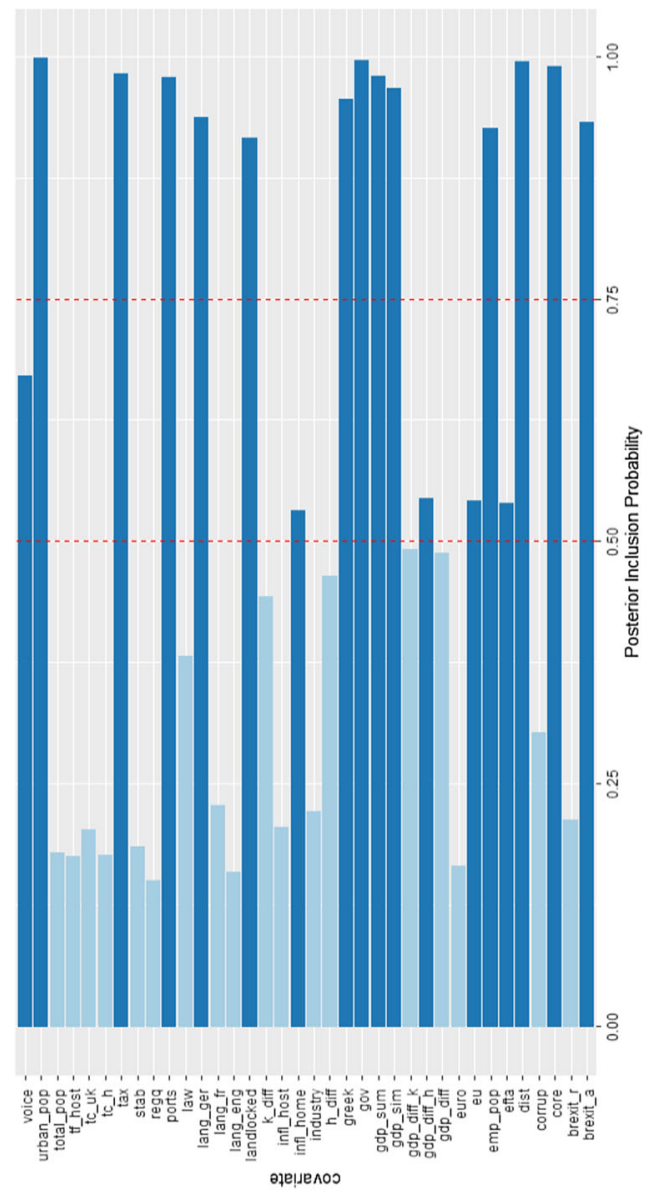

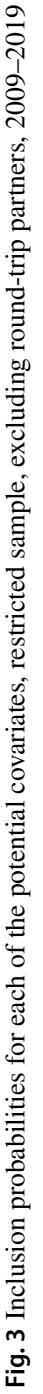




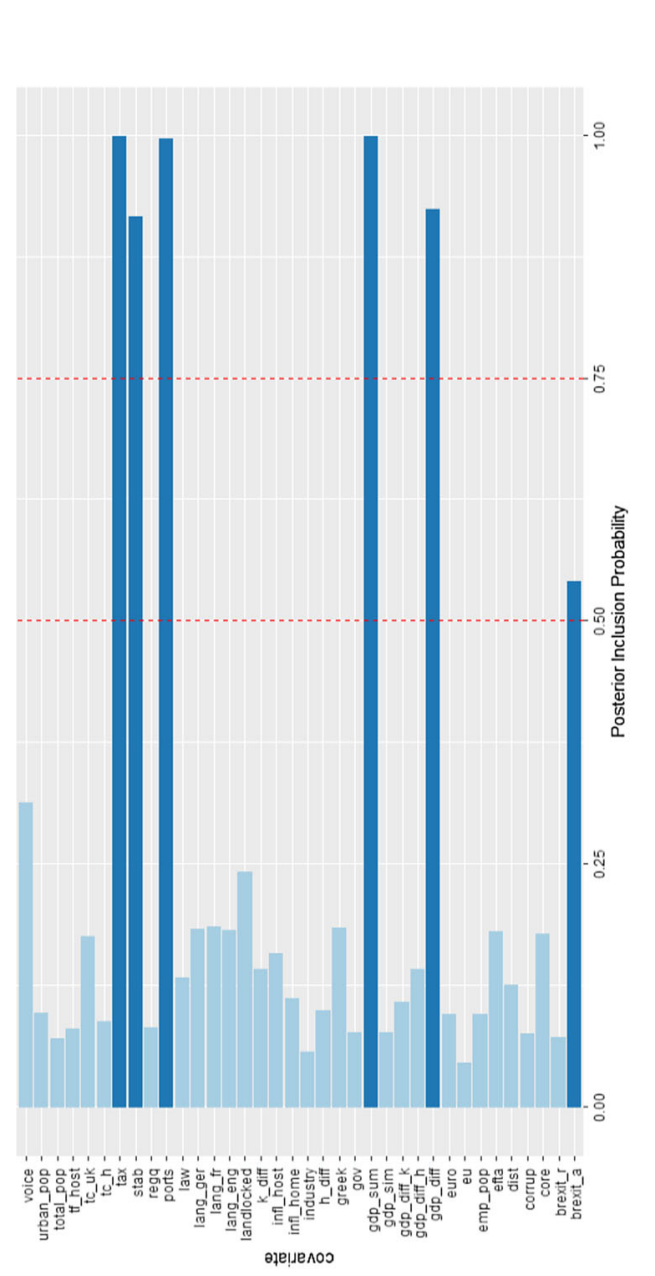

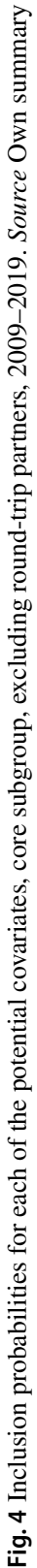




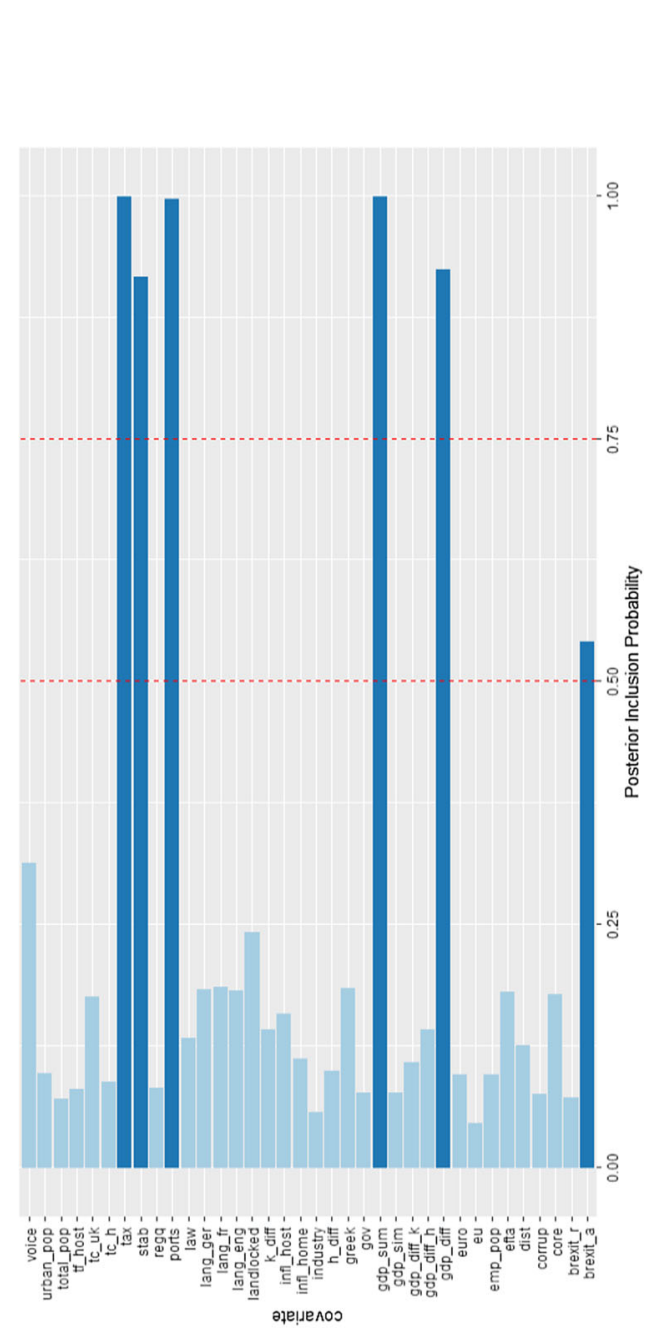

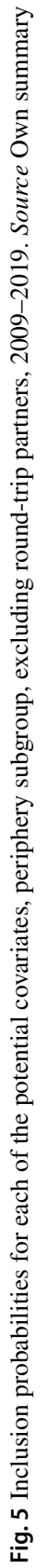


urban_pop: +2.08 ), landlocked dummy (landlocked: +0.98$)$, government effectiveness proxy (gov: -3.92 ), major seaport dummy (ports: +1.21 ), Brexit anticipation dummy (brexit_a: - 0.67), EU-core dummy (core: -1.69 ), round-trip FDI partner dummy (phantom: + 1.43), German language proxy (lang_ger: - 1.438), the Eurozone crisis dummy (greek: -1.51 ), and market size-physical capital difference interaction term (gdp_diff_k: - 0.18).

In the general case results, the horizontal motive is supported by positive coefficients on the covariates of joint market size, market size similarity, urban population of the host (due to how consumption is driven by urban areas), and seaport dummy (due to higher infrastructure level attracting FDI). Further, negative signs of the total population proxy and distance imply that MNEs favor markets with higher per-capita GDP in closer proximity to the parent economy. Then, in this case, positive signs on both landlocked and round-trip FDI dummies are likely to be driven by stocks located in Luxembourg, and Switzerland. Further, negative sign of government effectiveness can imply the willingness of MNEs to accept paying bribes in order to speed up the bureaucratic processes in the host economy (Lui 1985; Egger and Winner 2005), while negative sign of Brexit anticipation and the Eurozone crisis dummies suggest the impact of economic uncertainty on MNEs' FDI activity in the region. Lastly, the vertical FDI motive is supported by positive coefficient on the human capital difference variable (FDI seeking low-cost skilled labor) together with negative coefficients on EU-core, German language dummies, and market size-physical capital difference interaction term, which point toward vertical FDI in countries such as Czech Republic, Hungary, and Slovakia.

In comparison with Camarero et al. (2019), who study German OFDI, the results find strong statistical evidence in support for GDP-related measures, while high PIP values of total, and urban population, language proxy, distance as well as EU-core dummy are largely in line with their findings. Additionally, the results are somewhat close to what Blonigen and Piger (2011) obtain in their estimation, though, in our data, we find a much more pronounced role of hosts' institutional characteristics such as government effectiveness proxy having high PIP value. Finally, compared to the recent study by Camarero et al. (2021) on Japanese OFDI, our results are starkly different in regards of supporting the GDP-related covariates, as their results imply a pretty much nonexistent role of hosts' GDP covariates in BMA estimation.

We now investigate a different case using the estimates of real FDI stock data from Damgaard et al. (2019), who decompose cross-country FDI positions into real FDI and round-trip FDI using data on Special Purpose Entities (SPEs) and non-SPEs. ${ }^{15}$ Hence, they provide a detailed database, where both outward and inward FDI positions are broken down into two components: FDI by SPEs and non-SPEs. Then, we match data on British OFDI from their database for the selected round-trip partners using non-SPE-owned stocks and obtain the decomposed case results.

Figure 2 reports the results obtained using decomposed phantom stocks. The results indicate robust PIP values for the variables of human capital difference (h_diff: + 4.14), joint market size (gdp_sum: +5.48 ), geographical proximity (dist: -1.06 ), market

\footnotetext{
15 This is done by using ORBIS data for country pairs, their data cover 2009-2017, which we then extrapolate to fill additional years in our data: 2018, 2019.
} 
size similarity (gdp_sim: +2.22 ), urban population in the host country (urban_pop: $+2.15)$, tax revenues proxy (tax: +1.25$)$, landlocked dummy (landlocked: +0.83 ), government effectiveness proxy (gov: -3.75$)$, major seaport dummy (ports: +0.91 ), the EU-core dummy (core: - 1.63), round-trip FDI partner dummy (phantom: + 1.32), German language proxy (lang_ger: - 1.11), the Eurozone crisis dummy (greek: - 1.46), and market size-physical capital difference interaction term (gdp_diff_k: 0.16 ).

In comparison with the general case results, the difference is threefold. First, the total population covariate is by far no longer robust $(\mathrm{PIP}=0.47)$, and second, tax revenue proxy is now robust with positive coefficient, which suggests that there is a positive relationship between the volume of tax revenue relative to GDP of the host and inward FDI stocks. Further, because the tax revenue proxy retains its sign from the general case, it is possible to hypothesize that larger spending on infrastructure, transportations systems, and public investment attracts vertical FDI from British MNEs (Justesen 2008), with host economies of Denmark, Sweden, Norway, and Austria (tax revenue relative to GDP $>25 \%$ ) driving the positive sign of this parameter. In sum, the decomposed case results offer a more mixed picture of FDI motives because now MNEs are less interested in the total population of the given market, and there is a stronger relationship between inward FDI and tax revenue collection (which is transformed into domestic spending, and investment). Lastly, the significance level of Brexit anticipation is reduced to 0.8 PIP level, yet remains fairly high.

The analysis now considers a restricted case, where round-trip FDI partners are excluded from the studied sample. Figure 3 presents restricted case, the results indicate robust PIP values for the variables of joint market size (gdp_sum; + 6.67), distance (dist: -1.32 ), market size similarity (gdp_sim: +2.77 ), total urban and employed population (urban_pop; + 2.66; emp_pop: -2.524$)$, tax revenue proxy (tax: +1.69 ), government effectiveness proxy (gov: -3.80 ), seaport dummy (ports: +1.50 ), the EU-core dummy (core: - 1.99), German language proxy (lang_ger: - 1.15), and the Eurozone crisis dummy (greek: -1.92 ).

With round-trip partners removed from the partner pool, the human capital difference proxy is no longer robust (PIP $=0.46$ ), and the total employed population covariate is upgraded to robust with negative coefficient. The former result confirms the $H 2$ as in the previous cases, the presence of round-trip stock was driving the importance of the factor cost advantage in skilled labor, while the latter result suggests that MNEs are trying to take advantage of unemployed workers and labor availability in countries, whose labor cost would be initially low relative to the parent economy (Billington 1999), e.g. CEE countries. Further, previously found PIP values and estimated coefficients on the variables representing market size, total urban population, tax revenue collection, location of major seaport as well as negative signs of distance, government effectiveness, the EU-core dummy, German language proxy, and the Eurozone crisis dummy, hold their values and signs with round-trip partners removed.

Finally, the analysis examines British OFDI in two subgroups (East-West divide): pre-2000 and post-2000 EU accession members. Similar to the previous case, the estimation does not contain any round-trip partners or EFTA members (each subgroup has 121 observations). Figure 4 illustrates the results from the pre-2000 subgroup; robust PIP values are obtained for the variables of market similarity (gdp_sim: + 
3.61), rule of law (law: +4.75 ), and the Eurozone membership (euro: -1.83 ). The obtained results from the pre-2000 largely document the horizontal motive for FDI through market similarity and domestic institutions, while the negative sign on the Eurozone dummy indicates shifting of FDI to non-Euro economies of Denmark and Sweden. ${ }^{16}$

Figure 5 presents results obtained from the post-2000 subgroup; the results picture robust PIP for the variables of market size difference (gdp_diff: - 2.76), joint market size (gdp_sum: +18.56$)$, tax revenue proxy (tax: +3.28$)$, political stability of the host (stab: +1.09 ), and major seaport proxy (port: -5.14$)$. The results are mixed, with market size difference indicating vertical FDI, and joint market size suggesting horizontal FDI. Further, positive sign of the tax revenue proxy is driven by Malta, Latvia, Hungary, and Croatia (tax revenue relative to GDP $>20 \%$ ) suggesting vertical FDI due to public spending and domestic investments. Next, positive sign of the political stability variable supports the existing literature on FDI and domestic political stability that documents the importance of security and peace for MNEs operations in the host economy (Resnick 2001; Carmignani 2003; Busse and Hefeker 2007). In particular, the beneficiaries of the enhanced political stability of the last decade are CEE economies of Czech Republic, Poland, and Slovakia. Lastly, negative sign of the seaport proxy is a result of the fact that with the exception of Poland, the post-2000 accession members do not feature any high-volume sea transportation hubs (e.g. they are landlocked or have relatively smaller volume of sea trade via domestic infrastructure).

\section{Conclusion}

This paper investigated the determinants of British OFDI in the EU and the EFTA economies across 2009-2019 using the general theory of MNE location choice and BMA estimation. As the data show, the British MNEs continue to be one of the most active capital-exporting firms in the global economy. Their economic relationship with the EU and the EFTA economies has remained close from operational and profit-shifting points despite growing operational uncertainty surrounding the Eurozone crisis or anticipation of Brexit. The employed theoretical framework for the identification of FDI motives and covariate selection has generally been able to meet the proposed hypotheses.

The principal takeaway of the paper is threefold. First, the results highlight the importance of market size characteristics such as size, urban concentration, the rule of law, and the location of major sea trading hubs in attaining horizontal FDI in large (pre2004) EU economies. On the other hand, the impact of round-tripping is connected to factor cost advantages and geographical position. Second, we find the shift of vertical FDI to CEE and Nordic economies from the large core EU economies. Further, the results document the negative relationship between government effectiveness and inward FDI. Third, for pre-2004 EU accession members, the findings indicate the importance of infrastructure spending (or public investment) and enhanced political

16 Denmark and Sweden are the only non-Euro economies present in the pre-2000 subgroup. 
stability in attracting both vertical and horizontal FDI. Finally, the results document the negative effects of the Eurozone crisis and Brexit anticipation on FDI stock levels in the EU and the EFTA.

Overall, the empirical findings offer multiple points for discussion and potential research avenues. In particular, we think that close examination of an ongoing FDIshifting to the Nordic economies could be an interesting extension of this paper and contribute to the study of the East-West FDI structure in Europe. Next, round-tripping via the channel FDI remains a major methodological and data challenge as detailed data on firm-level transactions are extremely scarce and generally not available (Davies et al. 2018). As a result, currently existing cross-country national FDI data should be treated with greater care in future empirical research and undergo additional analysis before being employed to derive results and policy research. The discussed results should be treated with some caution as the employed methodology has several technical limitations, like potential endogeneity of the estimated signs, or selection bias due to log-linearized model specification.

Open Access This article is licensed under a Creative Commons Attribution 4.0 International License, which permits use, sharing, adaptation, distribution and reproduction in any medium or format, as long as you give appropriate credit to the original author(s) and the source, provide a link to the Creative Commons licence, and indicate if changes were made. The images or other third party material in this article are included in the article's Creative Commons licence, unless indicated otherwise in a credit line to the material. If material is not included in the article's Creative Commons licence and your intended use is not permitted by statutory regulation or exceeds the permitted use, you will need to obtain permission directly from the copyright holder. To view a copy of this licence, visit http://creativecommons.org/licenses/ by $/ 4.0 /$.

\section{Appendix}

See Figs. 6, 7, 8, and 9 and Tables 3, 4, 5, 6 and 7. 


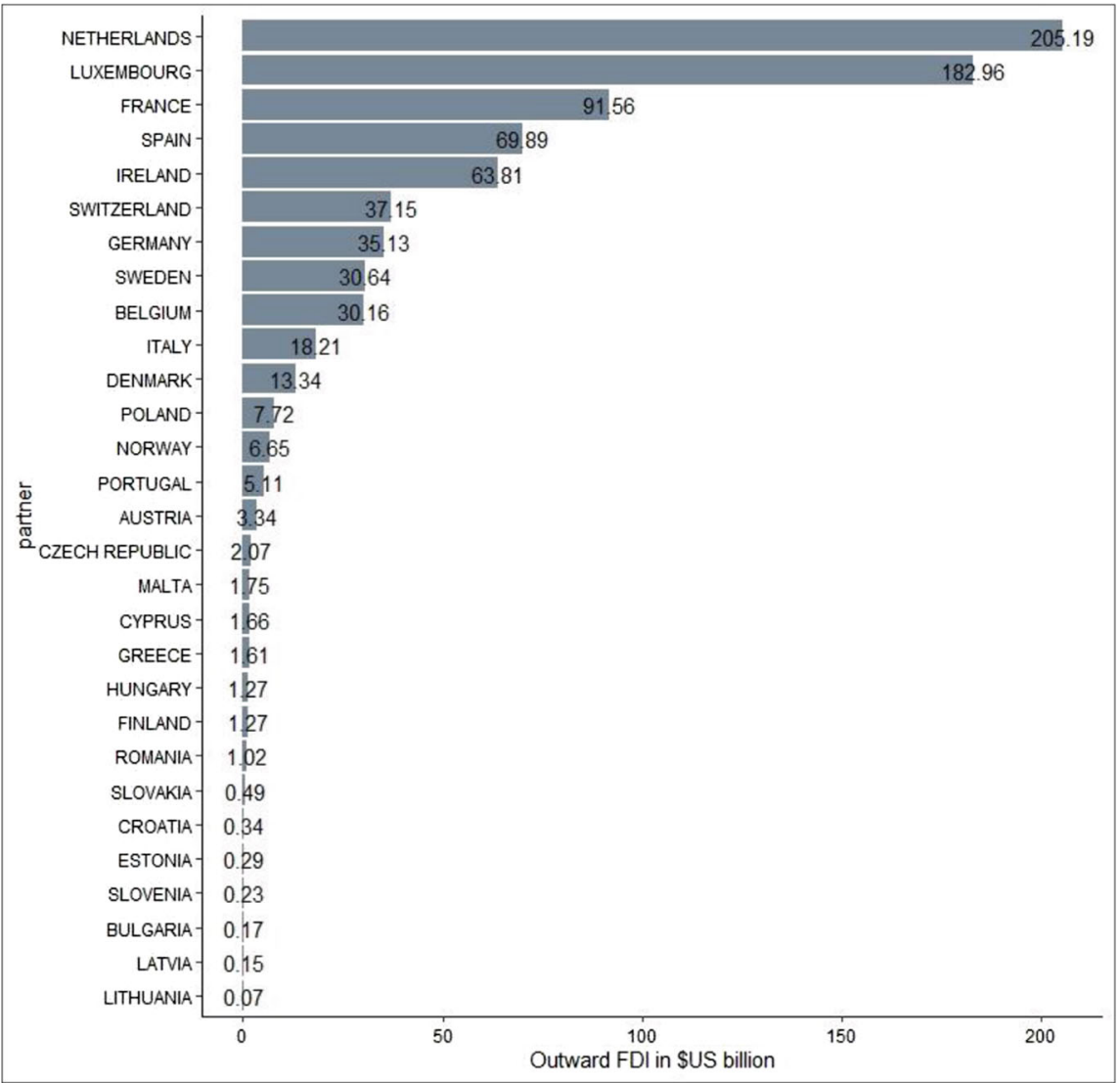

Fig. 6 Average outward FDI stocks of British MNEs, 2009-2019. Source Office for National Statistics, 2020 


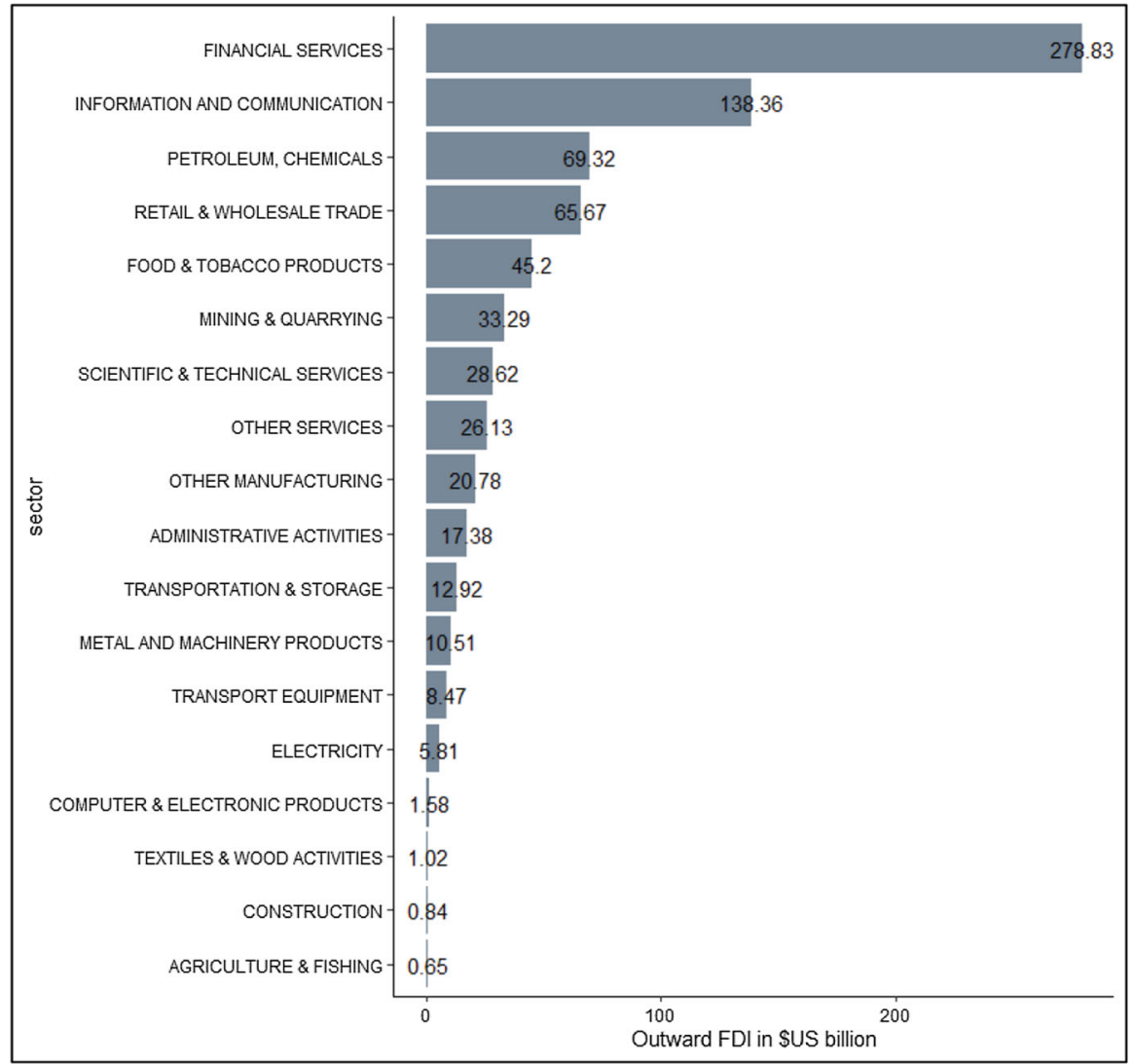

Fig. 7 Average sectoral distribution of outward FDI, 2016-2019. Source Office for National Statistics, 2020 


\begin{tabular}{|rr|}
\hline \multicolumn{2}{|c|}{ USS billion } \\
$\square$ & under 0.15 \\
$\square$ & 0.15 to 0.67 \\
$\square$ & 0.67 to 1.9 \\
$\square$ & 1.9 to 11 \\
$\square$ & 11 to 37 \\
$\square$ & over 37 \\
\hline
\end{tabular}

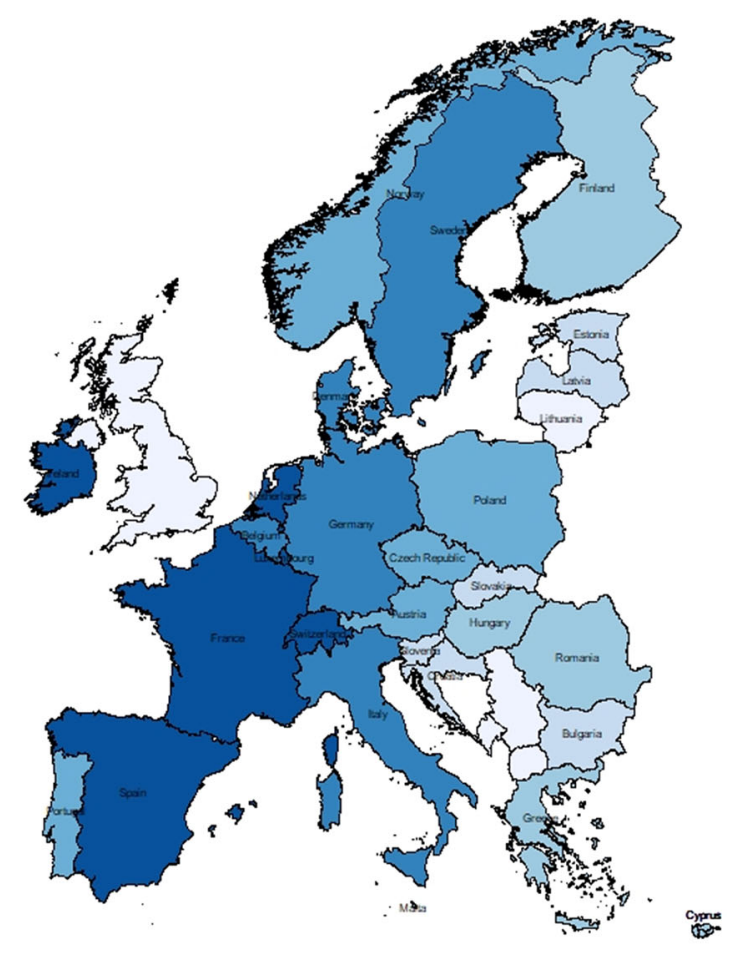

$\therefore$

Fig. 8 Distribution of British OFDI in the EU and EFTA, average, 2009-2019. Source Office for National Statistics, 2020 


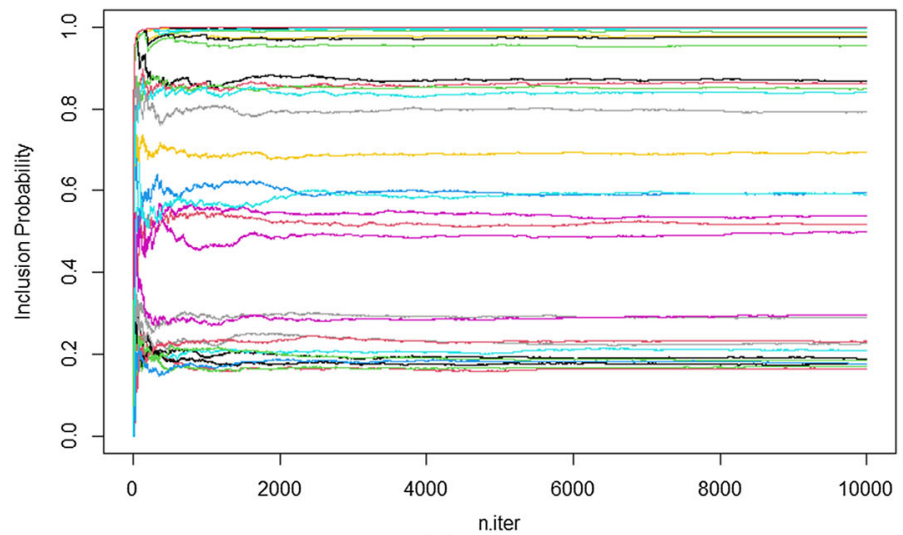

(a) global sample

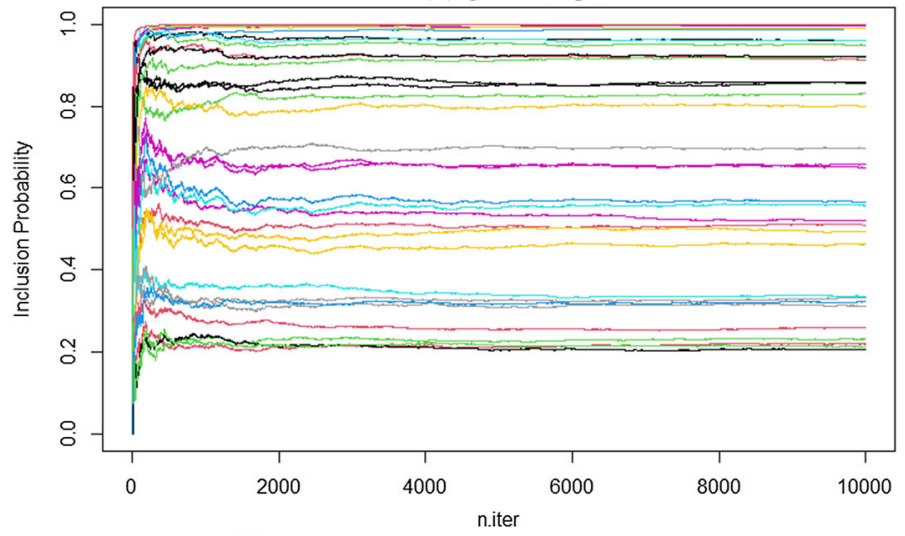

(b) global sample, with decomposed round-trip stocks

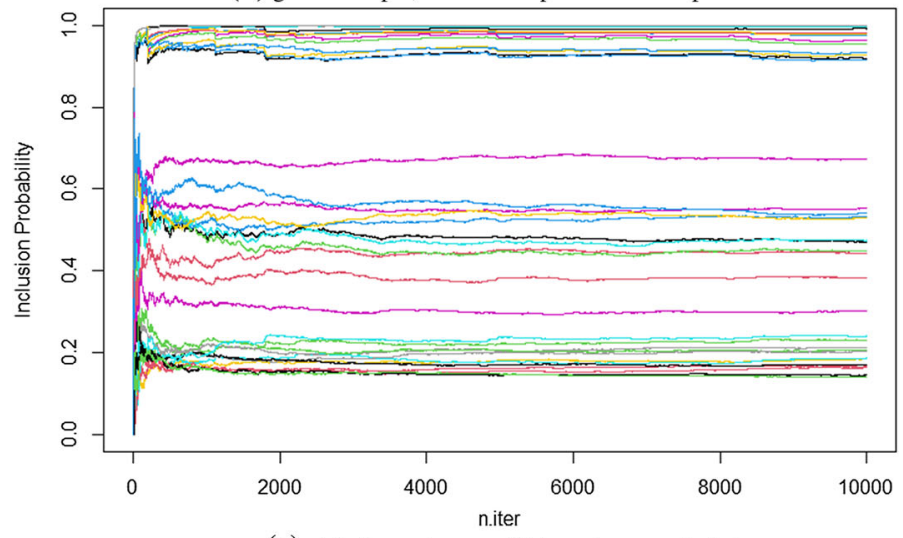

(c) global sample, round-trip partners excluded

Fig. 9 Evolution of the inclusion probabilities with the iterations in Gibbs sampling, first 10,000 iterations. a Global sample. b global sample, with decomposed round-trip stocks, Source Own summary. c Global sample, round-trip partners excluded, d core subgroup, round-trip partners excluded, Source Own summary. e Periphery subgroup, excluding round-trip partners. Source Own summary 


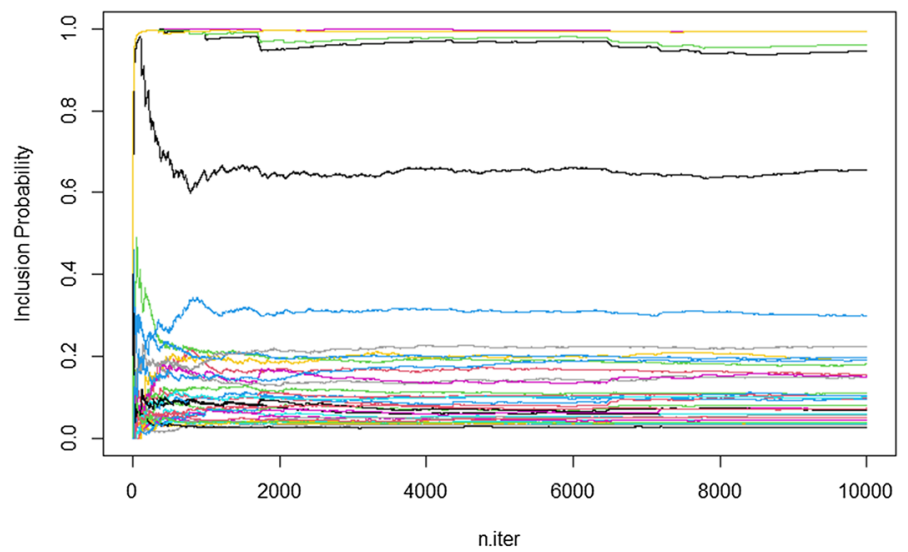

(d) core subgroup, round-trip partners excluded

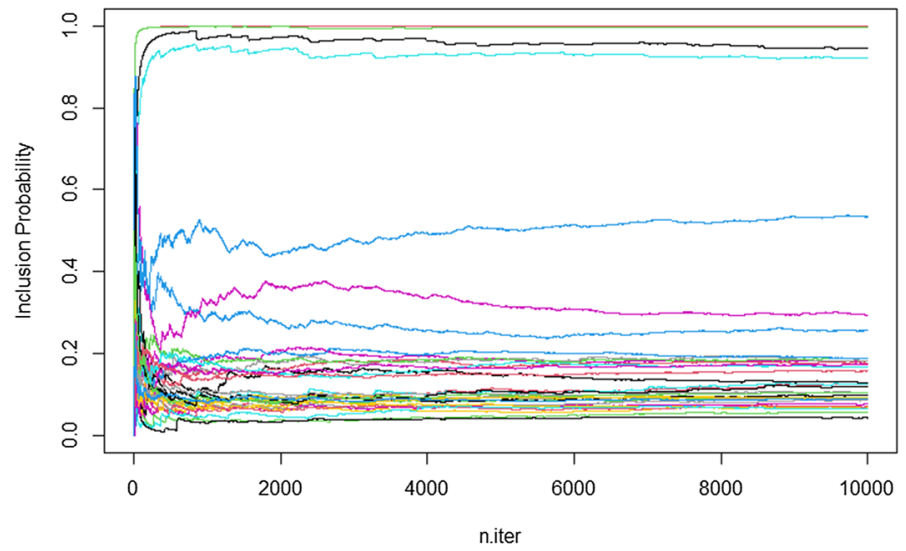

(e) periphery subgroup, excluding round-trip partners

Fig. 9 continued 
Table 3 Numerical results for the general case estimation

\begin{tabular}{|c|c|c|}
\hline Variable & Posterior inclusion probability & Post mean \\
\hline gpd_diff & 0.858 & -0.919 \\
\hline k_diff & 0.519 & -0.604 \\
\hline h_diff & 0.983 & 4.563 \\
\hline gdp_sum & 1.000 & 6.683 \\
\hline dist & 0.994 & -0.943 \\
\hline gdp_sim & 1.000 & 2.736 \\
\hline total_pop & 0.999 & -2.988 \\
\hline urban_pop & 0.999 & 2.081 \\
\hline emp_pop & 0.194 & -0.120 \\
\hline $\operatorname{tax}$ & 0.849 & 1.168 \\
\hline industry & 0.850 & -1.176 \\
\hline landlocked & 1.000 & 0.987 \\
\hline stab & 0.219 & 0.074 \\
\hline voice & 0.503 & 1.191 \\
\hline gov & 0.999 & -3.922 \\
\hline regq & 0.182 & -0.069 \\
\hline law & 0.176 & -0.017 \\
\hline corrup & 0.789 & 1.981 \\
\hline ports & 0.969 & 1.213 \\
\hline brexit_a & 0.975 & -0.676 \\
\hline brexit_r & 0.289 & 0.085 \\
\hline core & 0.997 & -1.696 \\
\hline tf_host & 0.162 & -0.0015 \\
\hline tc_uk & 0.174 & -0.002 \\
\hline $\mathrm{eu}$ & 0.591 & 0.896 \\
\hline efta & 0.593 & $\mathrm{C}^{\mathrm{a}}$ \\
\hline phantom & 0.999 & 1.430 \\
\hline lang_ger & 0.999 & -1.438 \\
\hline lang_fr & 0.823 & 1.004 \\
\hline lang_eng & 0.298 & -0.203 \\
\hline greek & 0.949 & -1.515 \\
\hline euro & 0.241 & -0.040 \\
\hline gdp_diff_k & 0.991 & -0.182 \\
\hline gdp_diff_h & 0.552 & 0.025 \\
\hline infl_home & 0.684 & 0.194 \\
\hline infl_host & 0.224 & 0.006 \\
\hline
\end{tabular}


Table 3 (continued)

Table 4 Numerical results for the decomposed case

\begin{tabular}{lll}
\hline Variable & Posterior inclusion probability & Post mean \\
\hline tc_h & 0.175 & 0.0007 \\
$\mathrm{~N}$ & 306 & \\
\hline
\end{tabular}

Robust OFDI determinants are in bold (PIP > 90\%). Source Own summary

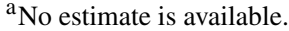

\begin{tabular}{|c|c|c|}
\hline Variable & Posterior inclusion probability & Post mean \\
\hline gpd_diff & 0.849 & -1.085 \\
\hline k_diff & 0.483 & -1.163 \\
\hline h_diff & 0.937 & 4.144 \\
\hline gdp_sum & 1.000 & 5.488 \\
\hline dist & 0.996 & -1.060 \\
\hline gdp_sim & 0.995 & 2.223 \\
\hline total_pop & 0.479 & -0.526 \\
\hline urban_pop & 0.997 & 2.154 \\
\hline emp_pop & 0.852 & -1.915 \\
\hline $\operatorname{tax}$ & 0.904 & 1.256 \\
\hline industry & 0.773 & -1.196 \\
\hline landlocked & 0.998 & 0.838 \\
\hline stab & 0.315 & 0.169 \\
\hline voice & 0.647 & 1.613 \\
\hline gov & 0.999 & $-\mathbf{3 . 7 5 0}$ \\
\hline regq & 0.192 & 0.0001 \\
\hline law & 0.294 & 0.383 \\
\hline corrup & 0.674 & 1.853 \\
\hline ports & 0.912 & 0.979 \\
\hline brexit_a & 0.805 & -0.412 \\
\hline brexit_r & 0.286 & 0.068 \\
\hline core & 0.956 & -1.632 \\
\hline tf_host & 0.193 & -0.002 \\
\hline tc_uk & 0.211 & -0.008 \\
\hline eu & 0.421 & 0.421 \\
\hline efta & 0.427 & $\mathrm{C}$ \\
\hline phantom & 0.987 & 1.322 \\
\hline lang_ger & 0.986 & -1.111 \\
\hline lang_fr & 0.573 & 0.441 \\
\hline
\end{tabular}


Table 4 (continued)

\begin{tabular}{lll}
\hline Variable & Posterior inclusion probability & Post mean \\
\hline lang_eng & 0.689 & -0.945 \\
greek & $\mathbf{0 . 9 1 3}$ & $-\mathbf{1 . 4 6 2}$ \\
euro & 0.140 & -0.030 \\
gdp_diff_k & $\mathbf{0 . 9 5 3}$ & $\mathbf{0 . 1 6 4}$ \\
gdp_diff_h & 0.512 & 0.042 \\
infl_home & 0.167 & 0.096 \\
infl_host & 0.298 & 0.010 \\
tc_h & 0.466 & 0.0009 \\
N & 306 & \\
\hline
\end{tabular}

$\overline{\text { Robust OFDI determinants are in bold (PIP }>90 \% \text { ). Source Own sum- }}$ mary

Table 5 Numerical results for the restricted case

\begin{tabular}{|c|c|c|}
\hline Variable & Posterior inclusion probability & Post mean \\
\hline gpd_diff & 0.489 & -1.040 \\
\hline k_diff & 0.444 & -1.930 \\
\hline h_diff & 0.465 & 1.496 \\
\hline gdp_sum & 0.981 & 6.674 \\
\hline dist & 0.996 & -1.329 \\
\hline gdp_sim & 0.968 & 2.777 \\
\hline total_pop & 0.180 & -0.020 \\
\hline urban_pop & 0.999 & 2.669 \\
\hline emp_pop & 0.926 & -2.524 \\
\hline $\operatorname{tax}$ & 0.983 & 1.693 \\
\hline industry & 0.222 & -0.224 \\
\hline landlocked & 0.916 & 0.605 \\
\hline stab & 0.186 & 0.084 \\
\hline voice & 0.671 & 1.783 \\
\hline gov & 0.996 & $-\mathbf{3 . 8 0 7}$ \\
\hline regq & 0.151 & 0.047 \\
\hline law & 0.382 & 0.903 \\
\hline corrup & 0.304 & 0.508 \\
\hline ports & 0.979 & 1.501 \\
\hline brexit_a & 0.933 & -0.673 \\
\hline brexit_r & 0.214 & 0.060 \\
\hline core & 0.990 & -1.998 \\
\hline tf_host & 0.177 & -0.004 \\
\hline tc_uk & 0.204 & -0.018 \\
\hline eu & 0.542 & 1.017 \\
\hline
\end{tabular}


Table 5 (continued)

\begin{tabular}{lll}
\hline Variable & Posterior inclusion probability & Post mean \\
\hline efta & 0.540 & $\mathrm{C}$ \\
phantom & $\mathrm{n} / \mathrm{a}$ & $\mathrm{n} / \mathrm{a}$ \\
lang_ger & $\mathbf{0 . 9 3 7}$ & $\mathbf{- 1 . 1 5 6}$ \\
lang_fr & 0.228 & -0.198 \\
lang_eng & 0.159 & $\mathrm{C}$ \\
greek & $\mathbf{0 . 9 5 7}$ & $-\mathbf{1 . 9 2 6}$ \\
euro & 0.166 & 0.031 \\
gdp_diff_k & 0.493 & -0.061 \\
gdp_diff_h & 0.545 & 0.070 \\
infl_home & 0.533 & 0.149 \\
infl_host & 0.206 & 0.008 \\
tc_h & 0.177 & 0.0007 \\
N & 253 & \\
\hline
\end{tabular}

Robust OFDI determinants are in bold (PIP > 90\%). Source Own summary

Table 6 Numerical results for the pre-2000 EU accession subgroup

\begin{tabular}{|c|c|c|}
\hline Variable & Posterior inclusion probability & Post mean \\
\hline gpd_diff & 0.060 & 0.021 \\
\hline k_diff & 0.173 & 0.088 \\
\hline h_diff & 0.190 & -0.034 \\
\hline gdp_sum & 0.092 & 0.026 \\
\hline dist & 0.052 & -0.004 \\
\hline gdp_sim & 0.977 & 3.613 \\
\hline total_pop & 0.194 & -0.154 \\
\hline urban_pop & 0.139 & 0.119 \\
\hline emp_pop & 0.646 & -0.892 \\
\hline $\operatorname{tax}$ & 0.106 & -0.059 \\
\hline industry & 0.070 & -0.071 \\
\hline landlocked & 0.300 & -0.256 \\
\hline stab & 0.042 & -0.014 \\
\hline voice & 0.042 & -0.053 \\
\hline gov & 0.033 & 0.007 \\
\hline regq & 0.059 & 0.096 \\
\hline law & 0.939 & 4.759 \\
\hline corrup & 0.059 & -0.081 \\
\hline ports & 0.953 & 1.943 \\
\hline
\end{tabular}


Table 6 (continued)

\begin{tabular}{lll}
\hline Variable & Posterior inclusion probability & Post mean \\
\hline brexit_a & 0.193 & 0.051 \\
brexit_r & 0.031 & -0.0008 \\
core & 0.068 & -0.025 \\
tf_host & 0.040 & 0.0001 \\
tc_uk & 0.032 & -0.0004 \\
eu & 0.027 & $\mathrm{C}$ \\
efta & $\mathrm{N} / \mathrm{A}$ & $\mathrm{N} / \mathrm{A}$ \\
phantom & $\mathrm{N} / \mathrm{A}$ & $\mathrm{N} / \mathrm{A}$ \\
lang_ger & 0.113 & -0.036 \\
lang_fr & 0.112 & 0.089 \\
lang_eng & 0.098 & $\mathrm{C}$ \\
greek & 0.155 & -0.138 \\
euro & $\mathbf{0 . 9 9 4}$ & $-\mathbf{1 . 8 3 4}$ \\
gdp_diff_k & 0.224 & -0.002 \\
gdp_diff_h & 0.073 & -0.001 \\
infl_home & 0.072 & -0.007 \\
infl_host & 0.037 & 0.003 \\
tc_h & 0.184 & -0.004 \\
N & 121 & \\
\hline
\end{tabular}

Robust OFDI determinants are in bold (PIP > 90\%). Source Own summary

Table 7 Numerical results for the post-2000 EU accession subgroup

\begin{tabular}{lll}
\hline Variable & Posterior inclusion probability & Post mean \\
\hline gpd_diff & $\mathbf{0 . 9 2 4}$ & $-\mathbf{2 . 7 8 6}$ \\
k_diff & 0.142 & 6.062 \\
h_diff & 0.099 & -1.424 \\
gdp_sum & $\mathbf{1 . 0 0 0}$ & $\mathbf{1 8 . 5 6 8}$ \\
dist & 0.126 & -2.237 \\
gdp_sim & 0.07 & -0.215 \\
total_pop & 0.071 & -0.053 \\
urban_pop & 0.097 & 0.617 \\
emp_pop & 0.096 & -1.213 \\
tax & $\mathbf{0 . 9 9 9}$ & $\mathbf{3 . 2 8 5}$ \\
industry & 0.057 & 0.092 \\
landlocked & 0.243 & 0.418 \\
stab & $\mathbf{0 . 9 1 7}$ & $\mathbf{1 . 0 9 0}$ \\
voice & 0.314 & 1.841 \\
\hline
\end{tabular}


Table 7 (continued)

\begin{tabular}{|c|c|c|}
\hline Variable & Posterior inclusion probability & Post mean \\
\hline gov & 0.077 & -0.364 \\
\hline regq & 0.082 & -0.326 \\
\hline law & 0.133 & -0.624 \\
\hline corrup & 0.076 & -0.108 \\
\hline ports & 0.994 & -5.146 \\
\hline brexit_a & 0.541 & -0.659 \\
\hline brexit_r & 0.072 & 0.008 \\
\hline core & N/A & N/A \\
\hline tf_host & 0.064 & -0.005 \\
\hline tc_uk & 0.175 & 0.033 \\
\hline eu & N/A & N/A \\
\hline efta & N/A & N/A \\
\hline phantom & N/A & N/A \\
\hline lang_ger & 0.184 & $\mathrm{C}$ \\
\hline lang_fr & 0.185 & $\mathrm{C}$ \\
\hline lang_eng & 0.182 & $\mathrm{C}$ \\
\hline greek & 0.185 & $\mathrm{C}$ \\
\hline euro & 0.095 & 0.079 \\
\hline gdp_diff_k & 0.108 & 0.027 \\
\hline gdp_diff_h & 0.142 & -0.198 \\
\hline infl_home & 0.112 & 0.130 \\
\hline infl_host & 0.158 & 0.018 \\
\hline tc_h & 0.089 & -0.002 \\
\hline $\mathrm{N}$ & 121 & \\
\hline
\end{tabular}

$\overline{\text { Robust OFDI determinants are in bold (PIP > 90\%). Source Own sum- }}$ mary

\section{References}

Antweiler W (2021) Pacific exchange rate service [online]. https://fx.sauder.ubc.ca/data.html

Barbieri MM, Berger JO (2004) Optimal predictive model selection. Ann Stat 32(3):870-897. https://doi. org/10.1214/009053604000000238

Bayarri MJ, Berger JO, Forte A, García-Donato G (2012) Criteria for Bayesian model choice with application to variable selection. Ann Stat 40(3):1550-1577. https://doi.org/10.1214/12-AOS1013

Bergstrand JH, Egger P (2007) A knowledge and physical capital model of international trade flows, foreign direct investment and multinational enterprises. J Int Econ 73(2):278-308. https://doi.org/10.1016/j. jinteco.2007.03.004

Billington N (1999) The location of foreign direct investment: an empirical analysis. Appl Econ 31(1):65-76. https://doi.org/10.1080/00036846.2019.12067087

Blonigen BA, Piger J (2011) Determinants of foreign direct investment (No. w16704). National Bureau of Economic Research

Blonigen BA, Piger J (2014) Determinants of foreign direct investment. Can J Econ 47(3):775-812. https:// doi.org/10.1111/caje.12091 
Bloom N, Bunn P, Chen S, Mizen P, Smietanka P, Thwaites G (2019) The impact of Brexit on UK firms (No. w26218). National Bureau of Economic Research. https://doi.org/10.3386/w26218

Breinlich H, Leromain E, Novy D, Sampson T (2020) Voting with their money: Brexit and outward investment by UK firms. Eur Econ Rev 124:103400. https://doi.org/10.1016/j.euroecorev.2020.103400

Busse M, Hefeker C (2007) Political risk, institutions and foreign direct investment. Eur J Polit Econ 23(2):397-415. https://doi.org/10.1016/j.ejpoleco.2006.02.003

Camarero M, Montolio L, Tamarit C (2019) What drives German foreign direct investment? New evidence using Bayesian statistical techniques. Econ Model 83:326-345. https://doi.org/10.1016/j.econmod. 2019.08.017

Camarero M, Moliner S, Tamarit C (2020) Is there a euro effect in the drivers of US FDI? New evidence using Bayesian Model Averaging techniques. Economics Department, Working Papers 2020/25, Universitat Jaume I, Castellón (Spain)

Camarero M, Moliner S, Tamarit C (2021) Japan's FDI drivers in a time of financial uncertainty. New evidence based on Bayesian Model Averaging. Jpn World Econ 57:101058. https://doi.org/10.1016/j. japwor.2021.101058

Campos NF, Coricelli F, Moretti L (2019) Institutional integration and economic growth in Europe. J Monet Econ 103:88-104. https://doi.org/10.1016/j.jmoneco.2018.08.001

Carmignani F (2003) Political instability, uncertainty and economics. J Econ Surv. https://doi.org/10.1111/ 1467-6419.00187

Carr DL, Markusen JR, Maskus KE (2001) Estimating the knowledge-capital model of the multinational enterprise. Am Econ Rev 91(3):693-708. https://doi.org/10.1257/aer.91.3.693

CEPII (2021) The gravity database [online]. Available at: http://www.cepii.fr/CEPII/en/bdd_modele/ presentation. asp $? \mathrm{id}=8$

Damgaard J, Elkjaer T, Johannesen N (2019) What is real and what is not in the global FDI network?. IMF Working Paper No. 19/274

Davies RB, Martin J, Parenti M, Toubal F (2018) Knocking on tax haven's door: multinational firms and transfer pricing. Rev Econ Stat 100(1):120-134. https://doi.org/10.1162/REST_a_00673

Dhingra S, Huang H, Ottaviano G, Paulo Pessoa J, Sampson T, Van Reenen J (2017) The costs and benefits of leaving the EU: trade effects. Econ Policy 32(92):651-705. https://doi.org/10.1093/epolic/eix015

Dhingra S, Sampson T (2019) Brexit Economics (No. 048). Centre for Economic Performance, LSE

Disdier AC, Mayer T (2004) How different is Eastern Europe? Structure and determinants of location choices by French firms in Eastern and Western Europe. J Comp Econ 32(2):280-296. https://doi.org/ 10.1016/j.jce.2004.02.004

Egger P, Winner H (2005) Evidence on corruption as an incentive for foreign direct investment. Eur J Polit Econ 21(4):932-952. https://doi.org/10.1016/j.ejpoleco.2005.01.002

Eicher TS, Helfman L, Lenkoski A (2012) Robust FDI determinants: Bayesian model averaging in the presence of selection bias. J Macroecon 34(3):637-651. https://doi.org/10.1016/j.jmacro.2012.01.010

Eurostat (2021) Maritime ports freight and passenger statistics [online]. https://ec.europa.eu/eurostat/ statistics-explained/index.php/Maritime_ports_freight_and_passenger_statistics

Feenstra RC, Inklaar R, Timmer MP (2015) The next generation of the Penn World Table. Am Econ Rev 105(10):3150-3182. https://doi.org/10.1257/aer.20130954

Forte A, Garcia-Donato G, Steel M (2018) Methods and tools for Bayesian variable selection and model averaging in normal linear regression. Int Stat Rev 86(2):237-258. https://doi.org/10.1111/insr.12249

Garcia-Donato G, Martinez-Beneito MA (2013) On sampling strategies in Bayesian variable selection problems with large model spaces. J Am Stat Assoc 108(501):340-352. https://doi.org/10.1080/01621459. 2012.742443

Gurshev O, Hamza S (2021) BITs, colony ties, and offshore centers. J Econ Integr 36(2):203-226. https:// doi.org/10.11130/jei.2021.36.2.203

Helpman E, Melitz MJ, Yeaple SR (2004) Export versus FDI with heterogeneous firms. Am Econ Rev 94(1):300-316. https://doi.org/10.1257/000282804322970814

Hines JR Jr, Rice EM (1994) Fiscal paradise: foreign tax havens and American business. Q J Econ 109(1):149-182. https://doi.org/10.2307/2118431

International Monetary Fund (2019) Glossary of Foreign Direct Investment Terms [online]. Available at https://www.imf.org/external/np/sta/di/glossary.pdf

Justesen MK (2008) The effect of economic freedom on growth revisited: new evidence on causality from a panel of countries 1970-1999. Eur J Polit Econ 24(3):642-660. https://doi.org/10.1016/j.ejpoleco. 2008.06.003 
Kneller R, Manderson E (2012) Environmental regulations and innovation activity in UK manufacturing industries. Resour Energy Econ 34(2):211-235. https://doi.org/10.1016/j.reseneeco.2011.12.001

Lui FT (1985) An equilibrium queuing model of bribery. J Polit Econ 93(4):760-781. https://doi.org/10. $1086 / 261329$

Markusen JR (2002) Multinational firms and the theory of international trade. MIT Press, Cambridge

Maza A, Gutiérrez-Portilla P, Villaverde J (2020) On the drivers of UK direct investment in the Spanish regions: a spatial Durbin approach. Growth Chang 51(2):646-675. https://doi.org/10.1111/grow.12378

Office for National Statistics (2020) Foreign direct investment involving UK companies [online]. Available at: https:/www.ons.gov.uk/economy/nationalaccounts/balanceofpayments/bulletins/ foreigndirectinvestmentinvolvingukcompanies/latest

Oyamada K (2020) How does BREXIT affect production patterns of multinational enterprises? J Policy Model 42(1):1-19. https://doi.org/10.1016/j.jpolmod.2019.08.002

Raftery AE (1995) Bayesian model selection in social research. Sociol Methodol 111-163

Resnick A (2001) Investors, turbulence, and transition: democratic transition and Foreign Direct Investment in nineteen developing countries. Int Interact 27(4):381-398. https://doi.org/10.1080/ 03050620108434991

Riker D, Wickramarachi H (2020) Review of literature on foreign direct investment, U.S. International Trade Commission Economics, Working Paper Series, Working Paper 2020-04-B

Sala-i-Martin X, Doppelhofer G, Miller RI (2004) Determinants of long-term growth: a Bayesian averaging of classical estimates (BACE) approach. Am Econ Rev. https://doi.org/10.1257/0002828042002570

Santos Silva JMC, Tenreyro S (2006) The log of gravity. Rev Econom Stat. https://doi.org/10.1162/rest.88. 4.641

Scott JG, Berger JO (2006) An exploration of aspects of Bayesian multiple testing. J Stat Plan Inference 136(7):2144-2162. https://doi.org/10.1016/j.jspi.2005.08.031

Serwicka I, Tamberi N (2018) Not backing Britain: FDI inflows since the Brexit referendum. UK Trade Policy Observatory Briefing Paper, 23

Simpson H (2012) How do firms' outward FDI strategies relate to their activity at home? Empirical evidence for the UK. World Econ 35(3):243-272. https://doi.org/10.1111/j.1467-9701.2011.01402.x

Welfens PJ, Baier FJ (2018) BREXIT and foreign direct investment: Key issues and new empirical findings. Int J Financ Stud 6(2):46. https://doi.org/10.3390/ijfs6020046

Welfens PJ (2017) An accidental Brexit: new EU and transatlantic economic perspectives. Springer

World Bank (2021) World Development Indicators [online]. https://datacatalog.worldbank.org/dataset/ world-development-indicators

Publisher's Note Springer Nature remains neutral with regard to jurisdictional claims in published maps and institutional affiliations. 